\title{
PENGUKURAN NILAI COLORIMETRY LAMPU PENERANGAN JALAN UMUM (PJU) LED MENGGUNAKAN ARRAY-SPECTRORADIOMETER
}

\section{Led Street Light Colorimetry Measurement Using Array-Spectroradiometer}

\author{
Yonan Prihhapso, Wiwin Farhania, Dini Suryani, dan Nelfyenny \\ Pusat Penelitian Metrologi - LIPI \\ Kompleks PUSPIPTEK, Gedung 420 Setu, Tangerang Selatan \\ e-mail: yonan.prihhapso@gmail.com
}

Diterima: 21 Februari 2018, Direvisi: 20 Maret 2018, Disetujui: 21 Maret 2018

\begin{abstract}
Abstrak
Lampu jalan LED memiliki nilai efikasi yang lebih tinggi dibandingkan lampu jalan tradisional. Konsekuensi dari efikasi yang tinggi pada suatu lampu adalah kualitas color rendering yang rendah. Tujuan dari penelitian ini adalah untuk mengukur nilai colorimetrylampu penerangan jalan umum LED. Untuk mengukur kualitas warna dari suatu sumber cahaya digunakan array spectroradiometer. Selain portabilitas dan kecepatan dalam pengukuran spectral, instrument ini memiliki keterbatasan yang harus dikarakterisasi. Salah satunya adalah respon spektral yang memiliki dampak yang cukup besar dalam pengukuran karena itu membutuhkan nilai koreksi dalam penggunaannya. Array spectroradiometer dikalibrasi terhadap lampu spectral irradiant standar untuk pengukuran magnitude dan lampu atomic untuk pengukuran akurasi panjang gelombang. Metode analisis digunakan untuk mengimbangi besarnya pengukuran spectral dari array spectroradiometer yang disebabkan oleh pergeseran spectral. Factor koreksi selanjutnya dikoreksi terhadap beberapa illuminan standard dan digunakan untuk perhitungan rendering index dari lampu jalan LED. Lampu jalan LED dengan nilai efikasi tinggi dapat menghasilkan rendering index pada level 80, tiga kali lebih besar dibandingkan lampu jalan tradisional (HPS) yang hanya mampu menghasilkan rendering index pada level 25. Pada penelitian selanjutnya, dapat dilakukan pengukuran terkait dengan reproduktivitas pengukuran array spektroradiometer yang dapat berdampak pada kualitas pengukuran color rendering.
\end{abstract}

Kata kunci: Color Rendering Index (CRI), lampu penerangan jalan umum LED, array spektroradiometer.

\section{Abstract}

LED Street light considered to have high efficacy compared to traditional street light. However there is a trade of from higher efficacy, which led to poor quality of color rendering. This research aims to measure the colorimetry value of LED street light. Array spectroradiometer commonly used to asses color quality of a light source. Aside from its portability and the speed of spectral measurement, this instruments has limitation that needs to be characterized. One that might have great effect is its spectral response, therefore correction needs to be applied. The array spectroradiometer calibrated against standard spectral irradiance lamp for its magnitude and atomic lamps for its wavelength accuracy. Analytical method applied to compensate the magnitude of spectral measurement of array spectroradiometer due to the spectral shift. The correction factor then validated against several standard illuminant, and applied to calculate rendering index of the LED Street light. With higher efficacy, LED Street light capable to produce rendering index in the level of 80 almost three times larger than traditional street light (HPS) that only can produce rendering index in the level of 25. Future study regarding the measurement reproducibility of an array spectrodiometer is needed, since this problem will affect the measurement quality of color rendering.

Keyword: Color Rendering Index(CRI), LED street light, , array spectroradiometer.

\section{PENDAHULUAN}

Sumber penerangan Solid State Lighting (SSL) seperti LED telah banyak menggantikan sumber penerangan tradisional. Karakterisasi performacolorimetry seperti colour rendering index (CRI), suhu warna colour temperature (CCT), dan koordinat kromatisitas (chromaticity coordinates) dari sumber penerangan tipe ini perlu dilakukan, karena pada umumnya LED memiliki nilai efikasi (lumen/Watt) yang tinggi. Sebuah sumber penerangan dengan nilai efikasi yang tinggi berakibat terhadap performa colour rendering yang rendah(Yoshi Ohno, 2006). Hal ini umumnya terjadi pada kasus sumber penerangan tipe fluoroscent dan mungkin juga terjadi pada sumber penerangan LED. 
Salah satu fungsi penerangan jalan (PJU) di kawasan perkotaan adalah menghasilkan kekontrasan antara objek dan permukaan jalan (BSN, 2008). Berdasarkan SNI 7391, salah satu jenis lampu jalan ditinjau dari karakteristik dan penggunaannya adalah lampu High Pressure Sodium (HPS). Lampu penerangan jalan umum (PJU) tipe HPS telah banyak digunakan untuk jalan tol, arteri, kolektor, persimpangan besar/luas, dan interchange. Lampu tipe HPS memiliki nilai efikasi yang cukup tinggi namun pengaruhnya terhadap warna objek (colour rendering) dinilai buruk. Saat ini terdapat lampu jenis LED yang mampu mendapatkan nilai efikasi pada rentang yang sama dengan daya yang jauh lebih rendah dari pada lampu PJU jenis HPS.

Dalam penelitian ini akan dibandingkan performa lampu PJU tipe LED dan HPS berdasarkan karakteristik nilai colorimetry terutama tingkat nilai Colour Rendering Index. Hal ini dilakukan untuk mengetahui apakah lampu PJU jenis LED mampu menggantikan lampu PJU jenis HPS baik dari efikasi maupun dari performa colorimetry lampu tersebut.

\section{TINJAUAN PUSTAKA}

Dokumen IES LM-79 telah banyak dijadikan rujukan dalam pengujian dan pengukuran sumber penerangan yang berbasis SSL. Dalam dokumen ini disebutkan beberapa parameter kelistrikan maupun parameter fotometri yang perlu dilakukan pengukurannya. Informasi fotometri yang diperlukan dalam pengukuran produk-produk SSL antar lain adalah total luminous flux (lumens), luminous efficacy ( $\mathrm{lm} / \mathrm{W})$, luminous intensity (candela), koordinat kromatisitas, CCT dan colour rendering index (lesna, 2008). Colour rendering index (CRI) adalah ukuran tingkat kesamaan persepsi warna secara psychophysical dari sebuah objek ketika berada di bawah sumber tes dengan ketika berada di bawah sumber referensi yang sesuai dengan melakukan penyesuaian adaptasi kroma (chromatic adaptation) (Al, 2011).

Dapat diartikan bahwa warna dari sebuah objek dapat mengalami perubahan relatif terhadap pengamat, ketika dikenai sumber cahaya satu dengan ketika dikenai sumber cahaya lain seperti terlihat pada Gambar 1. CRI memiliki dampak yang tidak terlalu besar dalam penerangan jalan, terkecuali untuk area pusat perkotaan dan/atau area dengan jumlah pejalan kaki yang cukup banyak (CIE, 2007b). Hal ini karena pada area ini diperlukan pencahayaan dengan kualitas yang bagus sehingga mampu mendukung penglihatan manusia, terutama untuk dapat membedakan warna dan detail dengan baik.

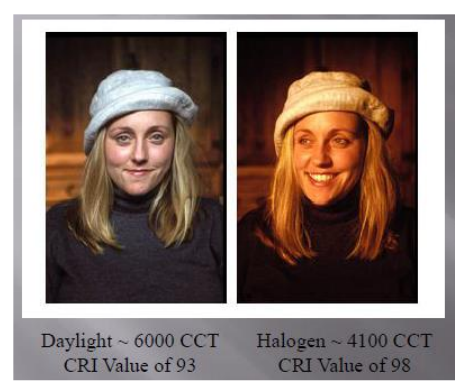

Gambar 1 Perbedaan persepsi warna (IES, Whitenessof $L E D)$.

Nilai CRI dapat dikalkulasi dengan menggunakan nilai spectral power distribution (SPD) dari sumber penerangan dengan memperhitungkan nilai colorimetric observer, $\bar{x}, \bar{y}$ dan $\bar{z}$. Sebuah sumber penerangan yang memiliki tingkat nilai rendering index $>90$ dikategorikan memiliki tingkat rendering warna yang bagus (Hunt \& Pointer, 2011).

Efisiensi energi sumber cahaya atau biasa dikenal sebagai luminous efficacy (efikasi sumber cahaya) biasanya diukur dalam lumens per watt $(\mathrm{Im} / \mathrm{W})$ yang dapat diartikan sebagai banyaknya cahaya yang dihasilkan oleh lampu setiap watt listrik yang dikonsumsi (Lingard, 2012). Tabel 1 menjelaskan mengenai perbandingan lampu penerangan jalan umum tipe HPS dan LED berdasarkan nilai efikasi yang mampu dihasilkan dengan penggunaan daya yang dibutuhkan oleh masing-masing jenis lampu.

Tabel 1 Nilai efikasi lampu PJU tipe HPS dan LED.

\begin{tabular}{|c|c|c|c|}
\hline $\begin{array}{l}\text { Tipe } \\
\text { Lampu }\end{array}$ & $\begin{array}{l}\text { Daya } \\
\text { (Watt) }\end{array}$ & $\begin{array}{c}\text { Luminous } \\
\text { Flux } \\
\text { (lumen) }\end{array}$ & $\begin{array}{l}\text { Efikasi } \\
\text { (Im/watt) }\end{array}$ \\
\hline $\begin{array}{l}\text { High } \\
\text { Pressure } \\
\text { Sodium } \\
\text { (HPS)-I }\end{array}$ & 452 & 47000 & 104 \\
\hline $\begin{array}{l}\text { High } \\
\text { Pressure } \\
\text { Sodium } \\
\text { (HPS)-II }\end{array}$ & 453 & 48599 & 107 \\
\hline LED-I & 118 & 13336 & 113 \\
\hline LED-II & 64 & 8469 & 133 \\
\hline
\end{tabular}

Kedua jenis lampu memiliki nilai efikasi yang hampir sama. Namun konsumsi daya yang dibutuhkan lampu LED jauh lebih sedikit dibandingkan dengan lampu HPS. Selain itu, LED cenderung lebih mudah dimanipulasi pada tingkat desain sehingga distribusi spektrumnya lebih mudah dikendalikan. Dengan kelebihan ini, 
LED sangat mungkin untuk mempunyai tingkat CRlyang lebih tinggi dari lampu PJU tradisional.

\section{METODE PENELITIAN}

Nilai spectral sebuah sumber diukur dengan melakukan scanning panjang gelombang cahaya dari panjang gelombang $380 \mathrm{~nm}$ hingga $780 \mathrm{~nm}$ menggunakan spectroradiometer. Array spectroradiometer banyak menjadi pilihan karena kemampuannya dalam akuisisi data spectral dalam jumlah yang besar sehingga dapat mempercepat akuisisi data dengan tingkat sensitivitas yang tinggi (Gaigalas, Wang, $\mathrm{He}$, \& DeRose, 2009). Hal ini berkaitan dengan komponen optis pada sebuah spectroradiometer, pada umumnya komponen optis ini terdiri dari optical input, entrance slit, elemen dispersi optis (grating), serta detektor array. Komponen dispersi optis memungkinkan cahaya yang masuk pada entrance slit tersebar pada daerah yang berbeda pada detektor array, tergantung pada panjang gelombangnya (Zong, Brown, Johnson, Lykke, \& Ohno, 2006). Pencacahan panjang gelombang menjadi sangat tergantung pada kemampuan komponen dispersi dan ukuran sensor array.

Ketika sebuah detektor array digunakan (baik tipe CCD atau CMOS) dalam sebuah spectroradiometer, setiap pixel dari detektor mewakili setiap panjang gelombang (GigahertzOptik Inc, n.d.). Sehingga ketika rentang pengukuran panjang gelombang semakin lebar maka jumlah pixel yang dibutuhkan pada detektor juga akan meningkat. Hal yang sama juga berlaku dengan bandwidth panjang gelombang, dengan bandwidth yang semakin kecil maka jumlah pixel detektor array juga akan meningkat. Persamaan (1) dapat digunakan untuk menentukan spesifikasi ukuran sensor sebuah array-spectroradiometer, sehingga didapatkan nilai akurasi panjang gelombang yang sesuai.

pixelnumber $=\frac{\mathrm{z}_{\mathrm{j}}-\mathrm{z}_{\mathrm{i}}}{\mathrm{bandwidth}} \times n$

dengan :

$\lambda_{i}-\lambda_{j}$ : rentang scanning panjang gelombang dalam $\mathrm{nm}$,

$\mathrm{n}$ : jumlah pixel perpanjang gelombang (pixel/nm).

Komponen optis serta jumlah pixel dapat mempengaruhi kualitas hasil pengukuran SPD, dalam hal ini pergeseran penunjukan panjang gelombang (wavelength shift). Pergeseran penunjukan panjang gelombang dapat memberikan kesalahan pengukuran nilai colorimetry, oleh karena itu perlu dilakukan pengukuran terhadap penunjukan panjang gelombang. Sebuah lampu atomic yang memiliki puncak-puncak gelombang yang tetap digunakan untuk melihat akurasi penunjukan dari array spectroradiometer, serta sebuah lampu spectral Irradiance (FEL) dengan daya $1000 \mathrm{~W}$ digunakan untuk mengkoreksi penunjukan tingkat Irradiance pada setiap panjang gelombang $\left(W / m^{2} . n m\right)$ (Nevas, Lindemann, Sperling, Teuber, \& Maass, 2009).

Sebuah spectroradiometer dari International Light yang memiliki sensor photodiode array 128 pixel digunakan untuk mengukur SPD sumber cahaya. Elemen dispersi instrumen ini menggunakan grating dengan akurasi panjang gelombang hingga $\pm 0,5 \mathrm{~nm}$, pada rentang ukur $380 \mathrm{~nm}-780 \mathrm{~nm}$. Instrumen ini memiliki digital spectral resolution sebesar 4,1 $\mathrm{nm}$, sehingga dengan rentang pengukuran sebesar $400 \mathrm{~nm}$ area sensor untuk setiap panjang gelombangnya adalah $1,3 \mathrm{pixel} / \mathrm{nm}$. Dynamic range pembacaan sensor ditentukan oleh nilai electronic resolution sebesar 14 bit, ketika sensor mendapatkan tegangan masukan sebesar $5 \mathrm{~V}$ pada tegangan maksimum koneksi USB mampu didapatkan pembacaan hingga tingkat $10^{-4}$.

Akurasi panjang gelombang ditentukan oleh kemampuan sebuah spectroradiometer memisahkan dua puncak panjang gelombang saling berdekatan pada satu spektrum dengan intensitas yang sama, atau umumnya disebut dengan Rayleigh Criterion (JETI Technische Instrumente $\mathrm{GmbH}$, 2005). Lampu atomic dengan elemen neon ( $\mathrm{Ne}$ ) digunakan untuk melihat penunjukan panjang gelombang array spectroradiometer, data pengukuran yang diperoleh akan digunakan untuk menentukan koreksi pergeseran panjang gelombang terukur.

Lampu tungsten $1000 \mathrm{~W}$ tipe FEL merupakan standar nilai Irradiance yang digunakan untuk melihat kesalahan penunjukkan tingkat Irradiance yang terukur pada setiap panjang gelombang padaarray spectroradiometer.

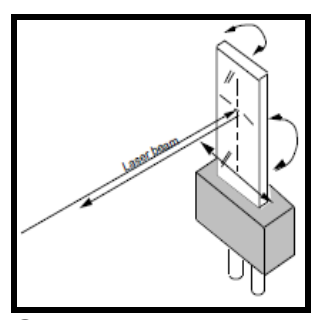

Gambar 2 Pelurusan posisi menggunakan lampjig (Yoshihiro Ohno, 1997). 
Lampu ini memiliki tipe filamen dengan bentuk coiled-coil dengan gelas dari bahan quartz, dasar lampu merupakan medium bi-post (G22) yang memungkinkan filamen selalu berada ditempat yang sama pada setiap pemasangan. Array spectroradiometer diletakkan pada jarak $0,5 \mathrm{~m}$ dari titik tengah filamen lampu, penempatan lampu dapat dilakukan dengan bantuan lampjig seperti pada Gambar 2.

Penuaan lampu (seasoning) merupakan hal yang sangat penting, karena akan mempengaruhi kestabilan sumber cahaya. Lampu FEL dinyalakan menggunakan sumber tegangan DC pada nilai arus 7,900A dan tegangan sebesar 107,67 volt. Nilaispectral IrradianceLampu FEL dari panjang gelombang $250 \mathrm{~nm}$ hingga $1100 \mathrm{~nm}$, dengan lebarinterval panjang gelombang $(\Delta \lambda)$ sebesar $5 \mathrm{~nm}$. Penggunaan $\Delta \lambda$ pada pengukuran SPD sebesar $10 \mathrm{~nm}$ atau $20 \mathrm{~nm}$ tidak direkomendasikan, hal ini dikarenakan akan menyebabkan penurunan akurasi yang cukup besar dan jika dipergunakan harus diperiksa untuk spektrum-spektrum khusus (CIE Division 1, 2004).

Simulasi menunjukkan tingkat kesalahan perhitungan colorimetric ketika menggunakan interval panjang gelombang $5 \mathrm{~nm} \quad(<0,03$ in $\Delta E_{a b}^{*}$ ), sedangkan pada interval $10 \mathrm{~nm}$ $\left(<0,15 \Delta E_{a b}^{*}\right)$ dan pada interval $20 \mathrm{~nm}\left(\approx 1 \Delta E_{a b}^{*}\right)$ (CIE, 2007a).

Nilai $C R I$ lampu PJU dikalkulasi dari data SPD hasil pengukuran menggunakan array spectrora-diometer yang telah dikoreksi. Sebuah sumber cahaya referensi diperlukan dalam menentukan nilai $C R I$, untuk itu dihitung nilai colorimetry berdasarkan SPD tersebut mengikuti flowchart pada Gambar 3a. Nilai colorimetry ini adalah koordinat kromatisitas $x, y, z$ serta nilaicorrelated color temperature (CCT) dari lampu PJU. Berdasarkan CIE 13.3:1995, nilai $C R I$ dihitung dari jarak koordinat kromatisitas dalam skala $\mathrm{CIE} \mathrm{U}^{*} \mathrm{~V}^{*} \mathrm{~W}^{*}$ antara delapan buah sampel warna Munsell, terhadap sumber cahaya referensi yang apabila sumber tes memiliki CCT dibawah $5000 \mathrm{~K}$ adalah Planckian radiator akan tetapi bila sumber tes memiliki CCT $>5000 \mathrm{~K}$ maka sumber referensi adalah CIE-D illuminant (CIE Division 1, 1995). Faktor radiansi spectral dari delapan buah sampel warna Munsell dapat dilihat pada gambar $3 \mathrm{~b}$, dan nilai $C R I$ (Ra) dihitung menggunakan persamaan 2 .

$$
\begin{aligned}
& R a=100-4.6 d_{i} \\
& R a=100-4.6\left(\frac{d_{1}+d_{2}+d_{3}+d_{4}+d_{5}+d_{h}+d_{3}+d_{m}}{g}\right)
\end{aligned}
$$

dimana:

$d_{i} \quad$ : jarak koordinat kromatisitas dalam skala $\mathrm{U}^{*} \mathrm{~V}^{*} \mathrm{~W}^{*}$

$d_{1}-d_{8}:$ jarak koordinat kromatisitas dari masing-masing sampel warna.

Ketidakpastian pengukuran pada CRI mengacu pada metode yang digunakan oleh $\mathrm{Y}$. Ohno (Y. Ohno, 2001), di mana nilai-nilai ketidakpastian baku didapatkan secara eksperimental. Diasumsikan semua komponen penyusun ketidakpastian pengukuran tidak saling berkorelasi, dan memiliki probability distribution function (PDF) rectangular.

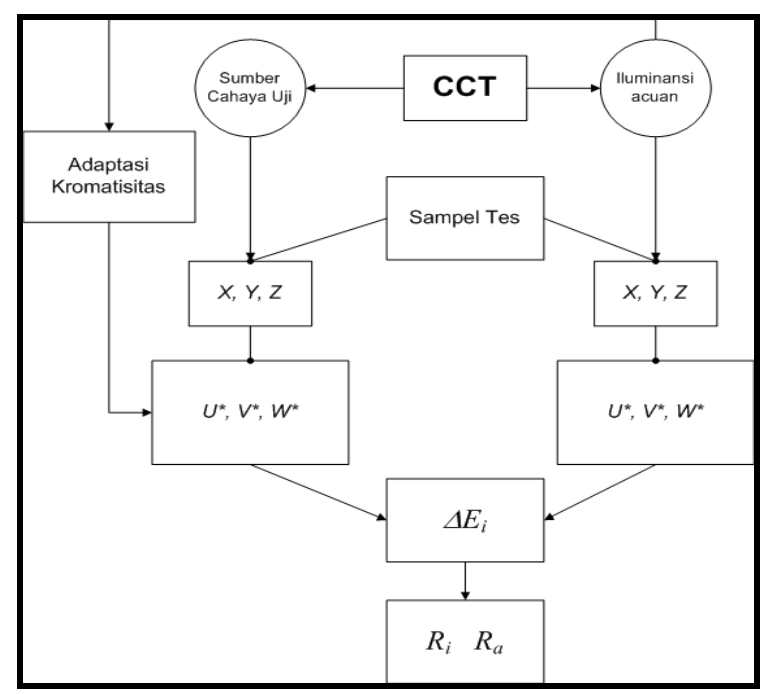

(a)

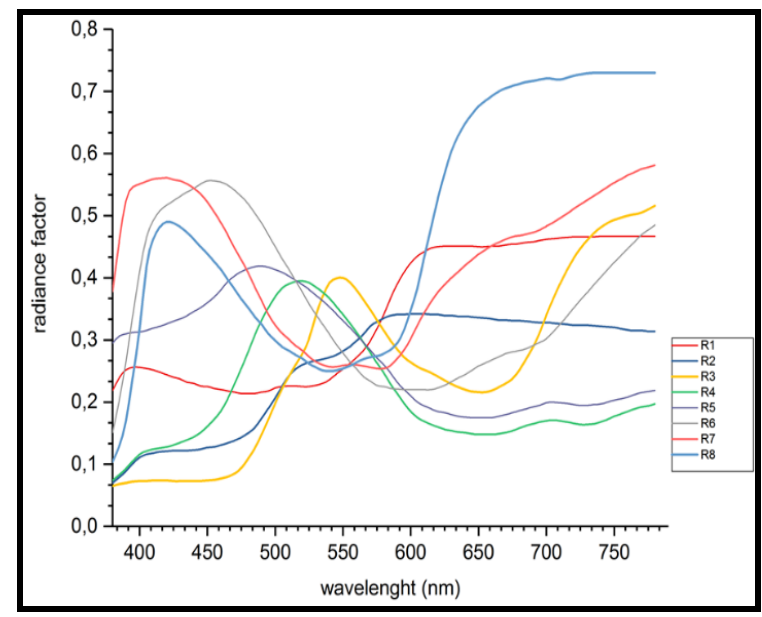

(b)

Gambar 3 Kalkulasi nilai CRI. a) Flowchart kalkulasi nilai CRI, b) Spectral radiance factor sampel warna Munsell.

\section{HASIL DAN PEMBAHASAN}

Hasil pengukuran penunjukan panjang gelombang array spectroradiometer dibanding- 
kan dengan puncak-puncak spektrum lampu atomic $\mathrm{Ne}$ seperti terlihat pada Tabel2. Hasil pengukuran panjang gelombang menunjukan perbedaan dengan nilai puncak spektrum $\mathrm{Ne}$, hal ini merupakan indikasi penunjukkan array spectroradiometer mengalami pergerseran. Pergeseran puncak panjang gelombang ini dapat mengakibatkan pergeseran penunjukkan nilai Irradiance ketika digunakan untuk mengukur SPD sebuah sumber cahaya, dalam hal ini lampu PJU. Hasil plotting data pengukuran dapat dilihat pada gambar berikut :

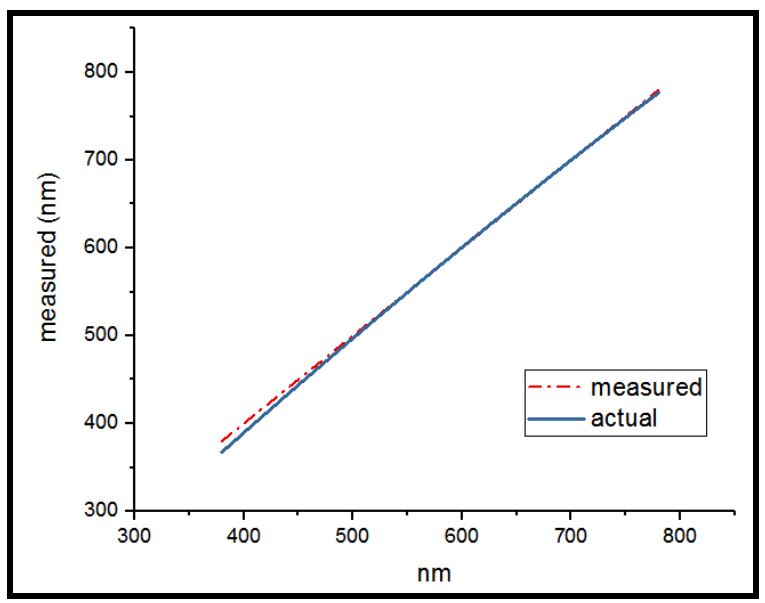

(a)

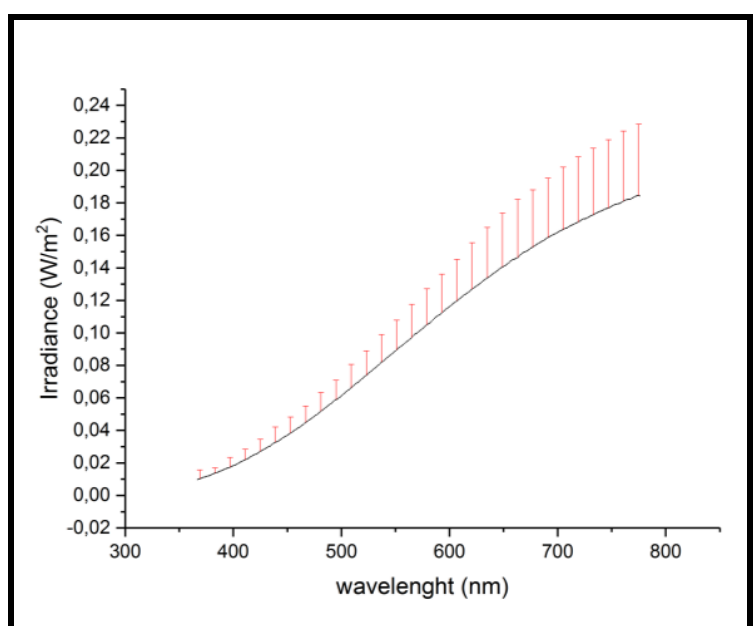

(b)

Gambar 4 a) Fitting hasil pengukuran spektrum $\mathrm{Ne}$ (kiri), b) Koreksi penunjukan tingkat Irradiance (kanan).

Gambar 4a, dimana terdapat selisih penunjukan panjang gelombang yang signifikan pada daerah panjang gelombang $800 \mathrm{~nm}$ dan terutama pada panjang gelombang bawah di sekitar panjang gelombang $400 \mathrm{~nm}$. Kesalahan ini mencapai $1 \%$ pada daerah $800 \mathrm{~nm}$ dan $4 \%$ pada daerah $400 \mathrm{~nm}$ atau senilai $13 \mathrm{~nm}$, akibatnya terdapat beberapa penunjukan panjang gelombang yang hilang. Hilangnya beberapa nominal panjang gelombang ini mengakibatkan data spectra yang seharusnya memiliki interval $\Delta \lambda 5 \mathrm{~nm}$ menjadi acak atau $\Delta \lambda$ menjadi bervariasi.

Perhitungan nilai CRI diawali dengan perhitungan nilai CCT seperti pada Gambar 3a. Dalam perhitungan CCT, digunakan nilai interval antar panjang gelombang sebesar $\Delta \lambda 5 \mathrm{~nm}$. Akan tetapi, karena urutan panjang gelombang menjadi acak karena pergeseran penunjukan array spectroradiometer sehingga perhitungan CCT menjadi tidak bisa dilakukan karena panjang gelombang yang diperlukan tidak terukur. Digunakan interpolasi linier terhadap penunjukan panjang gelombang dengan metode cubic spline untuk mendapatkan persamaan curve fitting, sehingga didapatkan nilai koreksi untuk setiap panjang gelombang.Interpolasi dilakukan dengan interval $\Delta \lambda 1 \mathrm{~nm}$ dari panjang gelombang $360 \mathrm{~nm}$ hingga $780 \mathrm{~nm}$ dengan akurasi nilai hingga 0,07\%.

Tabel 2 Hasil pengukuran spektrum $\mathrm{Ne}$.

\begin{tabular}{cc} 
Spektrum Neon & $\begin{array}{c}\text { Penunjukan } \\
\text { array spectroradiometer } \\
(n m)\end{array}$ \\
\hline 588,2 & 588 \\
\hline 614,3 & 613 \\
\hline 640,2 & 640 \\
\hline 653,3 & 652 \\
\hline 671,7 & 670 \\
\hline 693,0 & 693 \\
\hline 703,2 & 704 \\
\hline 724,5 & 725 \\
\hline 743,9 & 745 \\
\hline
\end{tabular}

Nilai Irradiance didapatkan dari lampu FEL pada setiap panjang gelombang $\left(W / m^{2} . n m\right)$ dengan $\Delta \lambda 5 \mathrm{~m}$ dari rentang $250 \mathrm{~nm}$ hingga 1050 $\mathrm{nm}$. Dalam perhitungan CRI rentang panjang gelombang yang digunakan antara $380 \mathrm{~nm}$ hingga $780 \mathrm{~nm}$ rentang ini pada umumnya digunakan dalam perhitungan nilai colorimetry. Hasil analisa penunjukkan panjang gelombang menggunakan lampu atomic $\mathrm{Ne}$ menunjukkan bahwa terjadi pergeseran penunjukan panjang gelombang, sehingga penunjukan array spectroradiometer tidak dimulai dari panjang gelombang $380 \mathrm{~nm}$ tetapi dari $367 \mathrm{~nm}$ hingga $776 \mathrm{~nm}$. Oleh karena itu, digunakan nilai 
Irradiance dari lampu FEL dari rentang $365 \mathrm{~nm}$ hingga $780 \mathrm{~nm}$ dengan interval $\Delta \lambda 5 \mathrm{~nm}$. Koreksi penunjukkan tingkat Irradiance pada setiap panjang gelombang dilakukan dengan menggunakan persamaan (3).

$m$ Correct $=\frac{\text { Reading } d \text { nst }}{\text { std lamp }}$.......

dimana :

mCorrect : rasio penunjukkan tingkat Irradiance $\left(W / m^{2} . n m\right)$ dari array spectroradiometer dengan tingkat Irradiance $\left(W / m^{2} . n m\right)$ dari lampu standard FEL, dan merupakan faktor kalibrasi untuk array spectroradiometer pada setiap panjang gelombang.

Data hasil interpolasi kemudian divalidasi terhadap lampu standar dengan tingkat kesalahan perhitungan parameter nilai colorimetry lebih kecil dari $0,1 \%$. Profil SPD hasil respon pengukuran array spectroradiometer ditunjukkan pada Gambar 4b, grafik merupakan nilai setelah dikoreksi sedangkan garis vertikal merupakan nilai kesalahan terhadap nilai SPD hasil pengukuran array spectroradiometer.

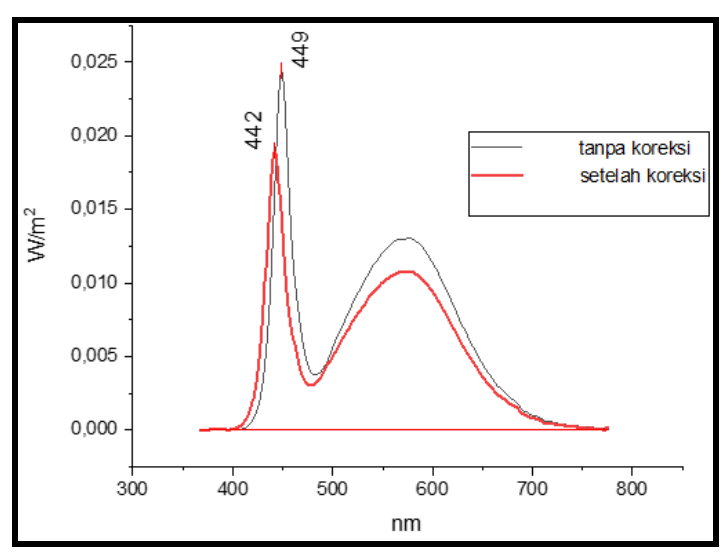

Gambar 5 SPD lampu PJU LED.

Array spectroradiometer digunakan untuk mengukur SPD lampu PJU, dalam penelitian ini digunakan 2 buah sampel lampu PJU jenis HPS berdaya $400 \mathrm{~W}$ sedangkan untuk jenis LED digunakan LED-I dengan daya $118 \mathrm{~W}$ dan LED-II dengan daya $64 \mathrm{~W}$. Hasil pengukuran profil SPD lampu PJU dilihat pada Gambar 5. Untuk PJU jenis LED 2 sebagai contoh, ketika koreksi tidak dilakukan maka penunjukan puncak maksimum SPD dari LED akan bergeser sejauh $7 \mathrm{~nm}$ menjadi $449 \mathrm{~nm}$ dari yang seharusnya $442 \mathrm{~nm}$.

Hal ini terjadi karena panjang gelombang yang paling dominan pada LED berada pada panjang gelombang $<500 \mathrm{~nm}$, sedangkan dari hasil pengukuran diketahui pada daerah ini mengalami pergeseran panjang gelombang 54 sebesar $4 \%$. Luasan area SPD juga lebih sempit setelah dibandingkan dengan sebelum dikoreksi nilai Irradiance-nya, sehingga bisa dikatakan bahwa ketika nilai Irradiance tidak dikoreksi perhitungan nilai $\mathrm{CRI}$ akan mengalami over estimate.

Hasil pengukuran nilai colorimetry lampu PJU dapat dilihat pada Tabel 3 dan 4, data pada table menunjukkan lampu jenis HPS tidak mengalami pergeseran penunjukkan puncak panjang gelombang, karena puncak panjang gelombang berada pada daerah linier. Nilai CCT lampu PJU di hitung menggunakan nilai SPD sehingga pergeseran nilai SPD akan sangat mempengaruhi nilai CCT. Dikarenakan lampu PJU tipe HPS tidak mengalami pergerseran puncak panjang gelombang sehingga nilai perhitungan CCT setelah nilai SPD dikoreksi tidak mengalami perubahan yang signifikan, berbeda dengan lampu PJU jenis LED.

Tabel 3 Nilai colorimetry lampu PJU HPS dan LED sebelum koreksi.

\begin{tabular}{lrrrr}
\hline \multirow{2}{*}{ Parameter } & \multicolumn{4}{c}{ Lampu PJU } \\
\cline { 2 - 5 } & HPS-I & HPS-II & LED-I & LED-II \\
\hline CCT $(\mathrm{K})$ & 2062,9 & 2055,5 & 6804,1 & 5363,9 \\
\hline CRI $(\mathrm{Ra})$ & 24,72 & 28,24 & 79,91 & 75,12 \\
\hline Peak $(n m)$ & 599 & 599 & 451 & 449 \\
\hline
\end{tabular}

Tabel 4 Nilai colorimetry lampu PJU HPS dan LED setelah koreksi.

\begin{tabular}{lrrrr}
\hline \multirow{2}{*}{ Parameter } & \multicolumn{4}{c}{ Lampu PJU } \\
\cline { 2 - 5 } & HPS-I & HPS-II & LED-I & LED-II \\
\hline CCT $(\mathrm{K})$ & 2104,5 & 2097,6 & 6732,9 & 5407,5 \\
\hline CRI $(\mathrm{Ra})$ & 24,95 & 28,47 & 77,35 & 73,75 \\
\hline Peak $(n m)$ & 599 & 599 & 444 & 442 \\
\hline
\end{tabular}

Apabila mengikuti flowchart perhitungan nilai CRI pada Gambar 3a diketahui bahwa perubahan nilai CCT memiliki korelasi positif terhadap nilai CRI, dimana semakin besar deviasi nilai CCT maka semakin besar pula deviasi nilai CRI yang didapat. $\mathrm{Hal}$ ini dikarenakan nilai CCT digunakan untuk menentukan sumber referensi pada perhitungan $\mathrm{CRI}$, nilai CCT sumber referensi bisa didapatkan dari Planckian radiator ataupun dari CIE $D$ illuminant.

Ketika nilai CCT lampu PJU telah diketahui maka sumber referensi diambil sesuai dengan nilai-nilai tristimulus $X, Y, Z$ yang setara. 
Nilai $\mathrm{CRI}$ dihitung dengan mengkonversi nilai tristimulus ke color space $\mathrm{U}^{*}, \mathrm{~V}^{*}, \mathrm{~W}^{*}$, sehingga didapatkan nilai respon sumber terhadap delapan buah sample warna Munsell.Perbedaan perhitungan nilai colorimetry sebelum dan setelah koreksi pada lampu PJU dapat dilihat pada Tabel 3 dan Tabel 4, perbedaan tingkat CRI pada lampu PJU LEDmasing-masing sebesar 3\% untuk LED 1, 2\% untuk LED 2 dan hanya $1 \%$ pada lampu PJU jenis HPS.

Ketidakpastian pengukuran dihitung menggunakan metode eskperimental dengan memperhatikan beberapa komponen yang memberi kontribusi terhadap nilai ketidakpastian pengukuran nilai CRI. Komponen spectral Irradiance standard lamp ditentukan pada batasan toleransi ketidakpastian dari seritifikat lampu FEL sebesar 2,5 \% hingga 1,4\% dengan faktor cakupan $k=2$ pada rentang panjang gelombang dari $365 \mathrm{~nm}$ hingga $780 \mathrm{~nm}$.

Perubahan nilai koordinat kromatisitas $\mathrm{x}$, y dan nilai CRI pada perubahan nilai sebesar toleransi digunakan sebagai nilai dari komponen ketidakpastian. Komponen aging of standard lampditentukan pada batasan toleransi perubahan nilai CCT dari lampu FEL dalam rentang burning time 50 jam, yaitu sebesar $3 \mathrm{~K}$. Batasan toleransi komponen wavelength didapatkan dari standar deviasi penunjukkan panjang gelombang array spectroradiometer. Komponen ambient temperature bernilai nol atau negligible karena array spectroradiometer memiliki kestabilan yang tinggi, dengan toleransi penggunaan pada rentang $10^{\circ} \mathrm{C}-40^{\circ} \mathrm{C}$.

Tabel 5 Ketidakpastian pengukuran CRI lampu PJU.

\begin{tabular}{llll}
\hline Components & $u(\Delta x)$ & $u(\Delta y)$ & $u(\Delta R a)$ \\
\hline $\begin{array}{l}\text { Spectral } \\
\text { Irradiance } \\
\text { standard lamp }\end{array}$ & 0.00028 & 0.00014 & 0.014 \\
\hline $\begin{array}{l}\text { Aging of } \\
\text { standard lamp }\end{array}$ & 0.00019 & 0.00007 & 0.00016 \\
\hline Wavelength & 0.00059 & 0.00072 & 1.5 \\
\hline $\begin{array}{l}\text { Reproducibility } \\
\text { Non-linearity of } \\
\text { spectroradiomet } \\
\text { er }\end{array}$ & 0.00013 & 0.00016 & 0.025 \\
\hline $\begin{array}{l}\text { Band pass filter } \\
\text { Ambient }\end{array}$ & 0.00006 & 0.00012 & 0.058 \\
\hline $\begin{array}{l}\text { Amperature } \\
\text { Current setting }\end{array}$ & 0.0 & 0.00029 & 0.23 \\
\hline \hline
\end{tabular}

\begin{tabular}{llll}
\hline Components & $u(\Delta x)$ & $u(\Delta y)$ & $u(\Delta R a)$ \\
\hline $\begin{array}{l}\text { combined } \\
\text { uncertainty }\left(u_{c}\right)\end{array}$ & 0.002 & 0.003 & 1.5 \\
\hline $\begin{array}{l}\text { expanded } \\
\text { uncertainty, } k=2 \\
(U)\end{array}$ & 0.005 & 0.006 & 3 \\
\hline
\end{tabular}

Nilai current setting bernilai nol, karena nilai ketidakpastiannya sudah termasuk dalam komponen reproducibility, komponen ini dicantumkan karena pada umumnya ketidakpastian pengukuran sumber cahaya sangat dipengaruhi oleh arus/tegangan pada lampu. Hasil perhitungan ketidakpastian pengukuran dapat dilihat pada Tabel 5.

\section{KESIMPULAN}

Lampu PJU tipe LED memiliki nilai efikasi yang lebih tinggi dari lampu HPS. Selain itu lampu tipe ini memiliki nilai colour rendering index $(\mathrm{Ra})$ tiga kali lebih tinggi dari jenis lampu HPS.Pada tingkat efikasi yang hampir sama lampu PJU jenis HPS mampu menghasilkan nilai colour rendering index pada tingkat 25-29 sedangkan lampu PJU jenis LED mampu menghasilkan nilai colour rendering pada tingkat 74-77. PuslitMetrologi LIPI mampu melakukan pengukuran nilai colorimetry lampu PJU yang tertelusur melalui lampu spectral Irradiance FEL 1000 W, dengan tingkat ketidakpastian pengukuran koordinat kromatisitas sebesar $x$ : $\pm 0,005 ; y: \pm 0,006$ dan colour rendering index (CRI) $\mathrm{Ra}: \pm 3$.

\section{UCAPAN TERIMA KASIH}

Terima kasih Pak Achalik, dan rekan-rekan laboratorium Radiometri Fotometri atas bantuan teknis dan dukungannya.

\section{DAFTAR PUSTAKA}

\section{Al, E. (2011). ILV: International Lighting Vocabulary. CIE. \\ Badan Standardisasi Nasional (BSN). (2008). SNI 7391:2008 - Spesifikasi Penerangan Jalan di Kawasan Perkotaan. Badan Standardisasi Nasional. Jakarta. \\ CIE. (2007a). Colorimetry: Understanding the CIE System. (J. Schanda, Ed.). Canada: Wiley. \\ CIE. (2007b). Road transport lighting for}


developing countries, 50 . https://doi.org/ISBN 9783901906619

CIE Division 1. (1995). CIE 013.3: Method of Measuring and Specifying Colour Rendering Properties of Light Sources.

CIE Division 1. (2004). CIE 15:24 Colorimetry, 3rd edition. CIE Technical Report (Vol. 552). https://doi.org/ISBN 3901906339

Gaigalas, A. K., Wang, L., He, H.-J., \& DeRose, P. (2009). Procedures for Wavelength Calibration and Spectral Response Correction of CCD Array Spectrometers. Journal of Research of the National Institute of Standards and Technology, 114(4),

215. https://doi.org/10.6028/jres.114.015

Gigahertz-Optik Inc. (n.d.). Basic of light measurement. Retrieved from https://www.gigahertz-optik.de/enus/basics-light-measurement/spectrradiometers/parameters/

Hunt, R. W. ., \& Pointer, M. . (2011). Measuring Colour, 4th edition. (M. A. Kriss, Ed.) (4th ed.). West Sussex: Wiley-IS\&T.

lesna. (2008). IES Approved Method: Electrical and Photometric Measurements of SolidState Lighting Products. IES LM-79-80. IES Subcommittee on Solid-State Lighting of the IES Testing Procedures Committee, 16. https://doi.org/ISBN 9780-87995-226-6

JETI Technische Instrumente GmbH. (2005).
Basics of Spectral Measurement. Measurement, (May), 1-53.

Lingard, R. (2012). Energy Efficiency of White LEDs. Pacific Northwest National Laboratory. Energy Efficiency and Renewable Energy, US Department of Energy.

Nevas, S., Lindemann, M., Sperling, A., Teuber, A., \& Maass, R. (2009). Colorimetry of LEDs with Array Spectroradiometers. Mapan - Journal of Metrology Society of India, 24(3), 153-162. https://doi.org/10.1007/s12647-0090019-5

Ohno, Y. (1997). Nist Measurement Services: Photometric Calibrations. NIST Special Publication 250-37.

Ohno, Y. (2001). Numerical Method for Colour Uncertainty. Proceedings CIE Expert Symposium on Uncertainty Evaluation, 8-11.

Ohno, Y. (2006). Optical metrology for LEDs and solid state lighting. Proc. SPIE, 6046, 604621-604625.

https://doi.org/10.1117/12.674617

Zong, Y., Brown, S. W., Johnson, B. C., Lykke, K. R., \& Ohno, Y. (2006). Simple spectral stray light correction method for array spectroradiometers. Applied Optics, 45(6), 1111-1119. https://doi.org/10.1364/AO.45.001111 